\title{
ROOF RUNOFF WATER AS SOURCE OF POLLUTION: A CASE STUDY OF SOME SELECTED ROOFS IN ORLU METROPOLIS, IMO STATE, NIGERIA
}

\author{
Ibe Francis Chizoruo ${ }^{1 a^{*}}$, Ibe Bridget Onyekachi ${ }^{2 b}$ \\ ${ }^{1}$ Department of Chemistry, Imo state University, P M B 2000 Owerri, Imo State Nigeria. \\ ${ }^{2}$ Department of Physical and Health Education, Alvan Ikoku Federal College of Education Owerri, \\ Imo State Nigeria.
}

*afrancispavo@yahoo.com and ${ }^{\mathrm{b}}$ mavisbright@yahoo.com

Keywords: Roofs, runoff, pollution, water, environment, Orlu

\begin{abstract}
Samples collected from different runoffs; AR, GMR, TR, ASR, and DR for aluminum roof, galvanized metal roof, thatch roof, asbestos roof and ambient rainfall respectively were analyzed for $\mathrm{pH}$, conductivity, turbidity, TDS, TSS, $\mathrm{NO}_{3}{ }^{-}, \mathrm{PO}_{4}{ }^{3-}, \mathrm{Cd}, \mathrm{Cu}, \mathrm{Fe}, \mathrm{Zn}$ and $\mathrm{Pb}$. The result indicates that the mean concentration of the parameters analyzed ranged from $5.8 \pm 0.39-$ $7.10 \pm 0.70, \quad 22.25 \pm 11.70-79.99 \pm 3.40 \mu \mathrm{Scm}^{-1}, \quad 1.47 \pm 0.43 \quad-\quad 46.53 \pm 1.60 \mathrm{mg} / 1, \quad 11.90 \pm 0.93 \quad-$ $59.83 \pm 1.62 \mathrm{NTU}, 15.53 \pm 0.70 \quad-204.53 \pm 5.08 \mathrm{mg} / 1, \quad 0.93 \pm 0.06 \quad-2.55 \pm 0.13 \mathrm{mg} / 1, \quad 1.33 \pm 0.22 \quad-$ $7.30 \pm 0.57 \mathrm{mg} / 1$ respectively for $\mathrm{pH}$, conductivity, TDS, turbidity, TSS, $\mathrm{PO}_{4}{ }^{3-}$ and $\mathrm{NO}_{3}{ }^{-}$, and the levels of the heavy metals (in $\mathrm{mg} / \mathrm{l}$ ); $\mathrm{Cd}, \mathrm{Cu}, \mathrm{Fe}, \mathrm{Zn}$ and $\mathrm{Pb}$ ranged from $0.0023 \pm 0.001-$ $0.0521 \pm 0.004,0.052 \pm 0.01-0.2483 \pm 0.02,0.0348 \pm 0.01-1.1120 \pm 0.07,0.0161 \pm 0.01-0.8093 \pm 0.02$ and $0.0106 \pm 0.01-0.0499 \pm 0.002$ respectively. Ranking of the heavy metal in roof runoff is in the order; $\mathrm{Fe}>\mathrm{Zn}>\mathrm{Cu}>\mathrm{Cd}>\mathrm{Pb}$. The result compared with WHO standard showed elevated level of the parameters analyzed with $\mathrm{Cd}$ and $\mathrm{Pb}$ exceeding the limit. Though the result of this study showed some variability which is an indication of the type of roofing material; air quality of the environment and industrial activity going on in the area. It could be deduced from the result that roof runoff may be a non point source of environmental pollution owning to the release of heavy metals and other pollutants into the environment, and increased concentration of some of the pollutants as reported by this study suggests that roof runoff water could impact negatively to the environment and if consumed without being treated may be injurious to human health.
\end{abstract}

\section{INTRODUCTION}

Harvested rainwater has been increasingly used for potable and non-potable purposes which are as a result of decrease in the availability and quality of traditional water resources [1]. Significant level of water quality reduction could be attributed to non point sources of pollution [2]. Roof runoff water has been identified as a major contributor to the pollution of streams, rivers and estuaries [3,4,5], resulting from increasing urbanization [6], since roof runoffs are discharged into the environment without being previously treated [7]. Roof surfaces in urban settlements contribute excess nutrients and toxic metals to receiving waters $[8,9,10,11]$, and these surfaces could cover from $12 \%$ in residential areas to $21 \%$ in commercial areas $[8,12]$. This therefore increases the overall toxic burden of the environment [13]. And the level of pollutants that may emanate from roof runoff depends on the roof materials, age, orientation and slope of the roofs, atmospheric depositions, rain events and meteorological conditions $[14,15,16]$.

In order to develop alternative technologies to control roof runoff pollution accurate data on the quality and properties of runoff pollution from different roof surfaces is required before it is mixed and transported in a sewer. This type of information seen to be lacking at present, though there has been some reports of roof runoff waters. High concentration of heavy metals like $\mathrm{Cd}, \mathrm{Cu}$, $\mathrm{Pb}$ and $\mathrm{Zn}$ has been reported in roof runoff $[17,18,19,20]$. Olaoye, and Olaniyan reported high level of $\mathrm{pH}, \mathrm{TH}, \mathrm{Al}, \mathrm{Cu}, \mathrm{NO}_{3}^{-} \mathrm{SO}_{4}^{-2}$ and presence of coliform bacteria in samples from asbestos, concrete and corrugated plastic roof, they noted that the aluminium roof was free from pathogenic 
contamination [21]. Also reports about roof runoff water have been made elsewhere [22,23]. The roof materials mainly used in Orlu Metropolis are made of a variety of substances ranging from plant materials, galvanized metal sheets, aluminum to asbestos and others which seen to have direct influence on the tendency for the release of toxins to the environment.

The need to evaluate pollution level emanating from rainwater samples in roof runoff in Orlu metropolis became necessary owning to paucity of reports on this issue about Orlu and its surroundings and the fact that there are significant number of people who still depend on harvested rainwater from roof runoff because of inadequate supply of portable water to every home in the town. In addition to the fact that Orlu (fig.1) is very close to Ohaji/Egbema/Oguta area of Imo State known for crude oil related activities and gas flaring.

\section{MATERIAL AND METHODS}

\section{Study area}

Orlu area of Imo State is located within the geographical coordinate $5^{\circ} 47^{\prime} 0^{\prime \prime}$ North and $7^{\circ} 2^{\prime} 0^{\prime \prime}$ East, within the tropical rainforest region with two distinct seasons; wet and dry seasons. In the recent time, the population of Orlu is fast increasing owning to urbanization and industrialization with a lot of commercial activities. Orlu is in the same zone with Ohaji/Egbema/Oguta area of Imo State where there has been crude oil exploration, drilling and gas flaring for more than forty years now.

\section{Sampling and preservation of sample}

Water samples were collected from four rain events in triplicate from each of the different roof types including sample from the ambient environment, referred to as direct rain water, in the locations referenced with Garmin GPSmap76. The study was conducted in Orlu, Imo State, within the months of June and August, 2013. The samples were collected from five different sources in triplicate in four different rain events at five different locations which in include Umuaka, Banana junction, Umuna, Ogboko junction and Umuago Urualla. The samples from aluminum roof, galvanized metal roof, thatch roof, asbestos roof and direct rainfall from ambient environment were labeled AR, GMR TR, ASR and DR respectively The parameters analyzed were $\mathrm{pH}$, electrical conductivity, total dissolved solid (TDS), turbidity, total suspended solid (TSS), phosphate $\left(\mathrm{PO}_{4}{ }^{-3}\right.$ ), nitrate $\left(\mathrm{NO}_{3}{ }^{-}\right)$and heavy metals $(\mathrm{Cd}, \mathrm{Cu}, \mathrm{Fe}, \mathrm{Zn}$, and $\mathrm{Pb})$. Polyethylene bowels and bottles for sampling were previously washed with detergent and $0.1 \mathrm{MHNO}_{3}$ and then rinsed with deionized water $[22,23]$. Contaminations of the samples were significantly reduced as samples were collected over elevated platform. Samples meant for heavy metal analysis were preserved according to $[24,25]$.

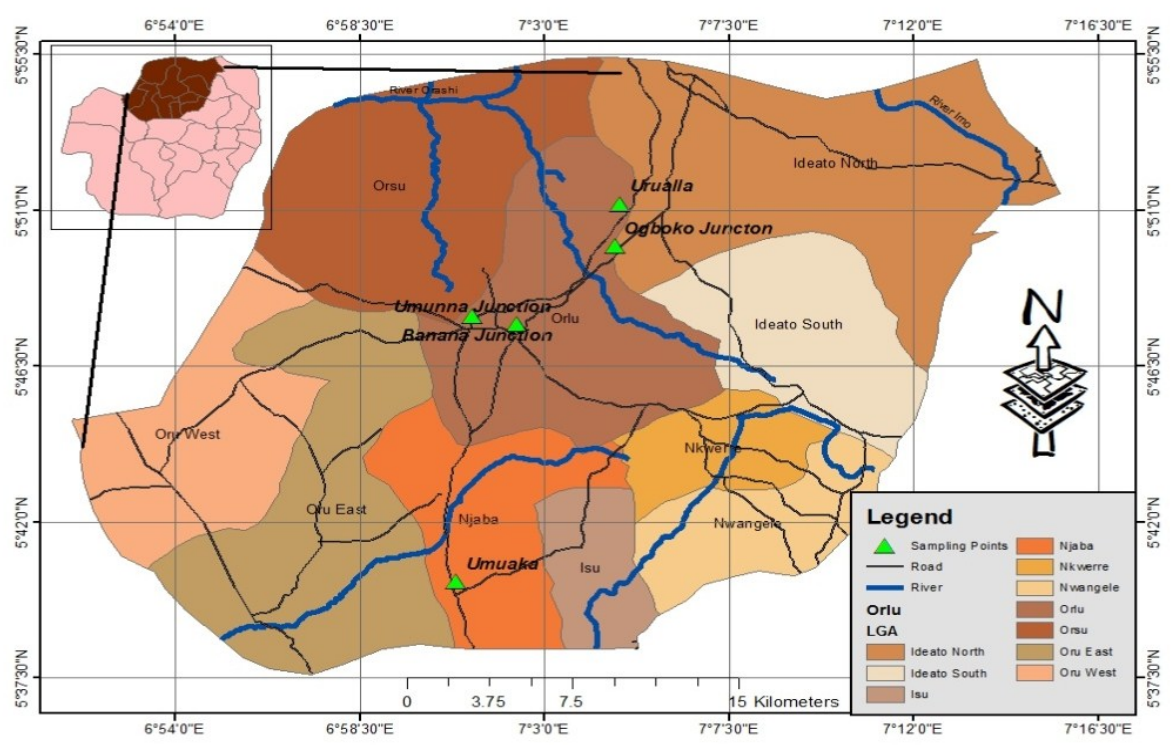

Fig. 1 Showing map of the study area 


\section{ANALYSIS OF SAMPLE}

$\mathrm{pH}$ and electrical conductivity (E.C) were measured with Hanna $\mathrm{pH}$ meter Hi 98107 and Hanna conductivity meter Hi98303. Turbidity, TDS and TSS were determined according to standard procedure $[24,26,27,28]$. Nitrate was determined by cadmium reduction method using Hanna H1 83200 multiparameter bench photometer at a wavelength of $525 \mathrm{~nm}$. $10 \mathrm{ml}$ of the sample was poured into two sample cells, one was used as blank to zero the instrument. Nitrate reagent was added to the second sample cell and inserted into the cell compartment and timed for 4 minutes 30 seconds. After this time the read button was displayed and result displayed in $\mathrm{mg} / \mathrm{l}$ of Nitrate. Also phosphate was determined by amino acid method using Hanna H1 83200 multiparameter bench photometer at $525 \mathrm{~nm} .10 \mathrm{ml}$ of the sample was poured into two sample cell bottles. One was used as blank to zero the instrument and 10 drops of H19371 A-O molybdate reagent and a packet of Hi9371B phosphate HR reagent B was added to the second sample cell bottle. It was gently shaken to dissolve and inserted into the cell compartment and timed for 5 minutes. At the end of this time the read button was pressed and result displayed in $\mathrm{mg} / \mathrm{l}$ of phosphate. Heavy metals $(\mathrm{Cd}, \mathrm{Cu}, \mathrm{Fe}$, $\mathrm{Zn}$ and $\mathrm{Pb}$ ) were analysed in the sample using atomic absorption spectrometer AAS, Agilent FS 240 AAS (USA). The metals were quantified by appropriate calibration curves prepared in the same acid matrix with standard solution of the metals [29].

\section{Quality Control}

Glasswares and polythene bottles used were soaked in $0.01 \mathrm{MHNO}_{3}$ overnight, washed, rinsed with deionized water and allowed to dry. The reagents that were used in this work were of analytical grade standard. The reagents $\mathrm{HCl}, \mathrm{HNO}_{3}$ and metal standard were supplied by Chemscience , Owerri.

\section{Statistical Analysis}

All the results of this work were analyzed with Microsoft Excel 2007 version which was presented as mean of standard deviation, minimum and maximum values.

\section{RESULTS AND DISCUSSION}

Table 1 is the result of physiochemical analysis showing mean values, minimum values, maximum values and the standard deviations while fig. 2 to fig. 5 is the chart representation of the results. From table 1 and fig 2, it is observed that the mean $\mathrm{pH}$ values ranged from $5.8 \pm 0.39-7.10 \pm$ 0.70 and the values are in the order $\mathrm{DR}<\mathrm{AR}<\mathrm{GMR}<\mathrm{TR}<\mathrm{ASR}$. This indicates that all the samples were acidic, indicating presence of acidic oxides in the atmosphere ${ }^{12}$. The acidic nature of ambient rainwater may cause the chemical compounds (such as cadmium, copper, lead, zinc, and chromium) from roofing materials to leach into the harvested rainwater [30,31]. The mean $\mathrm{pH}$ value of the harvested runoff samples are within the WHO drinking water standard range of 6.5 to 8.5 which could be used for domestic purposes. Similar studies have reported an increase in $\mathrm{pH}$ value from ambient rainwater to harvested roof runoff water $[7,32,33]$.

The mean conductivity as shown in table 1 and fig. 2 ranged from $22.25 \pm 11.70-79.99 \pm$ $3.40 \mu \mathrm{Scm}^{-1}$, the mean values of the conductivity are in the order TR $>$ ASR $>$ AR $>$ DR $>$ GM R. The result is typical of roof runoff water [33,34]. The sample from thatch roof runoff showed significantly high conductivity when compared with other roof runoff samples. And these values agree with reports made in similar studies [13,35].

The values for TDS (table land fig.4) vary from $(1.47 \pm 0.43) \mathrm{mg} / \mathrm{l}$ for DR $(46.53 \pm 1.60) \mathrm{mg} / \mathrm{l}$ for TR. The results showed elevated level of TDS when compared with other samples this followed by ASR. This could be attributed to the tendency of this roof to retain more precipitation [2], which could facilitate vigorous decomposition of the roof surfaces and as well being released with roof runoff. TDS correlates with E.C, the higher the E.C the greater the TDS [36]. The result is in the order TR $>$ ASR $>$ AR $>$ GMR $>$ DR which are within the WHO limit of 1000mg/l.

The mean turbidity value ranged from $11.90 \pm 0.93-59.83 \pm 1.62 \mathrm{NTU}$ as shown in table 1 and fig.4. The least value was obtained from DR while the most turbid is that from TR and this is in the 
order $\mathrm{TR}>\mathrm{AR}>\mathrm{ASR}>\mathrm{GMR}>\mathrm{DR}$. The elevated value for thatch roof is not unexpected owning to its organic nature as noted for TDS.

The results as shown (tab.1 and fig.4) indicates that the TSS values varies from $(15.53 \pm 0.70)$ $\mathrm{mg} / \mathrm{l}$ in DR to $(204.53 \pm 5.08) \mathrm{mg} / \mathrm{l}$ in TR. The level of TSS observed is in the order, $\mathrm{TR}>\mathrm{ASR}>\mathrm{GMR}>\mathrm{AR}>\mathrm{DR}$, the level of TSS may depend on the dry days, roughness of the surface and rain intensity [37] Elevated level of TSS can serve as carriers of toxics, which readily cling to suspended particles [32].

The mean phosphate level varies from $(0.93 \pm 0.06) \mathrm{mg} / \mathrm{l}$ in DR to $(2.55 \pm 0.13) \mathrm{mg} / \mathrm{l}$ in $\mathrm{TR}$, and values are in the order $\mathrm{DR}<\mathrm{GMR}<\mathrm{AR}<\mathrm{ASR}<\mathrm{TR}$. The phosphate level in roof runoff samples was greater than direct rain water from ambient air (table 1 and fig4). Again the concentration of phosphate were greater in TR runoff followed by ASR, this may be due to the ability of these roofs to retain contaminants [6]. In thatch roof, the fertilizer used during plant establishment could be the probable source of phosphate [38].

All the samples including that from ambient air contain elevated level of nitrate (table1 and fig.4). The concentration ranged from $(1.33 \pm 0.22) \mathrm{mg} / \mathrm{l}$ in DR from ambient rain to (7.30 \pm 0.57$)$ $\mathrm{mg} / \mathrm{l}$ in TR runoff water sample and the values are in the order

Table 1 Showing result of physiochemical analysis of roof runoff samples

\begin{tabular}{|c|c|c|c|c|c|c|c|}
\hline Parameters & Unit & & Roof type & & & & WHO \\
\hline & & AR & GMR & TR & ASR & DR & \\
\hline $\mathrm{pH}$ & & $6.60 \pm 0.64$ & $6.65 \pm 0.57$ & $6.88 \pm 0.36$ & $7.10 \pm 0.70$ & $5.80 \pm 0.39$ & $6.5-8.5$ \\
\hline MIN & & 5.70 & 6.00 & 6.40 & 6.30 & 5.40 & \\
\hline MAX & & 7.20 & 7.30 & 7.20 & 7.90 & 6.30 & \\
\hline E.C & $\mu \mathrm{S} / \mathrm{cm}$ & $50.43 \pm 2.18$ & $22.25 \pm 11.70$ & $79.99 \pm 3.40$ & $65.68 \pm 7.18$ & $33.05 \pm 3.35$ & 100 \\
\hline MIN & & 48.40 & 18.40 & 76.50 & 58.20 & 28.70 & \\
\hline MAX & & 53.50 & 25.80 & 84.30 & 75.40 & 36.50 & \\
\hline Turbidity & NTU & $18.11 \pm 1.30$ & $13.19 \pm 0.85$ & $59.83 \pm 1.62$ & $15.01 \pm 1.20$ & $11.90 \pm 0.93$ & 50 \\
\hline MIN & & 16.75 & 12.76 & 57.85 & 13.96 & 10.51 & \\
\hline MAX & & 20.34 & 13.63 & 62.31 & 16.25 & 13.63 & \\
\hline TDS & $\mathrm{mg} / \mathrm{l}$ & $10.34 \pm 5.62$ & $7.88 \pm 0.58$ & $46.53 \pm 1.60$ & $13.19 \pm 0.76$ & $1.47 \pm 0.43$ & 1000 \\
\hline MIN & & 9.20 & 7.30 & 44.80 & 12.30 & 1.14 & \\
\hline MAX & & 11.75 & 8.52 & 48.20 & 14.20 & 2.06 & \\
\hline TSS & $\mathrm{mg} / \mathrm{l}$ & $48.51 \pm 2.39$ & $92.93 \pm 6.50$ & $204.53 \pm 5.08$ & $189.2 \pm 6.48$ & $15.53 \pm 0.70$ & 50 \\
\hline MIN & & 46.30 & 84.50 & 199.80 & 184.20 & 14.60 & \\
\hline MAX & & 51.40 & 98.40 & 210.30 & 193.60 & 16.30 & \\
\hline Nitrate & $\mathrm{mg} / \mathrm{l}$ & $3.85 \pm 1.41$ & $3.68 \pm 0.84$ & $7.30 \pm 0.57$ & $4.35 \pm 0.95$ & $1.33 \pm 0.22$ & 50 \\
\hline MIN & & 2.20 & 2.80 & 6.50 & 3.40 & 1.10 & \\
\hline MAX & & 5.30 & 4.80 & 7.80 & 5.40 & 1.60 & \\
\hline Phosphate & $\mathrm{mg} / \mathrm{l}$ & $1.75 \pm 0.13$ & $1.38 \pm 0.17$ & $2.55 \pm 0.13$ & $2.23 \pm 0.25$ & $0.93 \pm 0.06$ & \\
\hline MIN & & 1.60 & 1.20 & 2.40 & 1.90 & 0.89 & \\
\hline MAX & & 1.90 & 1.60 & 2.70 & 2.50 & 1.02 & \\
\hline $\mathrm{Cd}$ & $\mathrm{mg} / \mathrm{l}$ & $0.019 \pm 0.007$ & $0.0349 \pm 0.005$ & ND & $0.052 \pm 0.004$ & $0.002 \pm 0.001$ & 0.003 \\
\hline MIN & & 0.0131 & 0.0302 & ND & 0.0486 & 0.0012 & \\
\hline MAX & & 0.0281 & 0.0412 & ND & 0.0561 & 0.0034 & \\
\hline $\mathrm{Cu}$ & $\mathrm{mg} / \mathrm{l}$ & $0.2483 \pm 0.02$ & $0.1878 \pm 0.02$ & $0.0520 \pm 0.01$ & $0.397 \pm 0.02$ & $0.012 \pm 0.00$ & \\
\hline MIN & & 0.2301 & 0.1280 & 0.0430 & 0.3740 & 0.0112 & \\
\hline MAX & & 0.2710 & 0.2340 & 0.0610 & 0.4230 & 0.0140 & \\
\hline $\mathrm{Fe}$ & $\mathrm{mg} / \mathrm{l}$ & $0.507 \pm 0.23$ & $1.1120 \pm 0.07$ & $0.0348 \pm 0.01$ & $0.636 \pm 0.04$ & $0.382 \pm 0.04$ & 2.00 \\
\hline MIN & & 0.4812 & 1.0210 & 0.0230 & 0.5800 & 0.3310 & \\
\hline MAX & & 0.5312 & 1.2030 & 0.0450 & 0.6840 & 0.4230 & \\
\hline $\mathrm{Zn}$ & $\mathrm{mg} / \mathrm{l}$ & $0.577 \pm 0.03$ & $0.8093 \pm 0.02$ & ND & $0.552 \pm 0.32$ & $0.016 \pm 0.01$ & 3.00 \\
\hline MIN & & 0.5420 & 0.7850 & ND & 0.0713 & 0.0101 & \\
\hline MAX & & 0.6210 & 0.8210 & ND & 0.7320 & 0.0221 & \\
\hline $\mathrm{Pb}$ & $\mathrm{mg} / \mathrm{l}$ & $0.015 \pm 0.004$ & $0.0224 \pm 0.01$ & ND & $0.049 \pm 0.002$ & $0.010 \pm 0.006$ & 0.01 \\
\hline MIN & & 0.0121 & 0.0080 & ND & 0.0484 & 0.0023 & \\
\hline MAX & & 0.0210 & 0.0412 & ND & 0.0522 & 0.0142 & \\
\hline
\end{tabular}


$\mathrm{TR}>\mathrm{ASR}>\mathrm{AR}>\mathrm{GMR}>\mathrm{DR}$. Also higher level of nitrate was observed in TR runoff compared to others followed by ASR runoff. The mean value for all the samples exceeded the WHO permissible limit of $50 \mathrm{mg} / \mathrm{l}^{-1}$. This is an indication of atmospheric pollution by nitrate which could be deposited on the surface of the roof. The higher values observed in TR and ASR runoff water though within WHO permissible limit of $45 \mathrm{mg} / 1$ could be attributed to higher retention capacity of the roofing materials and degradation of plant material in the case of thatch roof in a study of road and roof runoff waters as a source of pollution in a big urban agglomeration (reported Higher concentration of nitrate in the range of 0.92-62.000 mg/l were reported in road and roof runoff in Didansk, Polaul [5]. Similarly,Olaoye and Olaniyan reported nitrate range of 31.90-39.00 mg/l in their study of the quality of rainwater from different roof material in Ogbomoso north L.G.A., Oyo State f Nigeria [21].

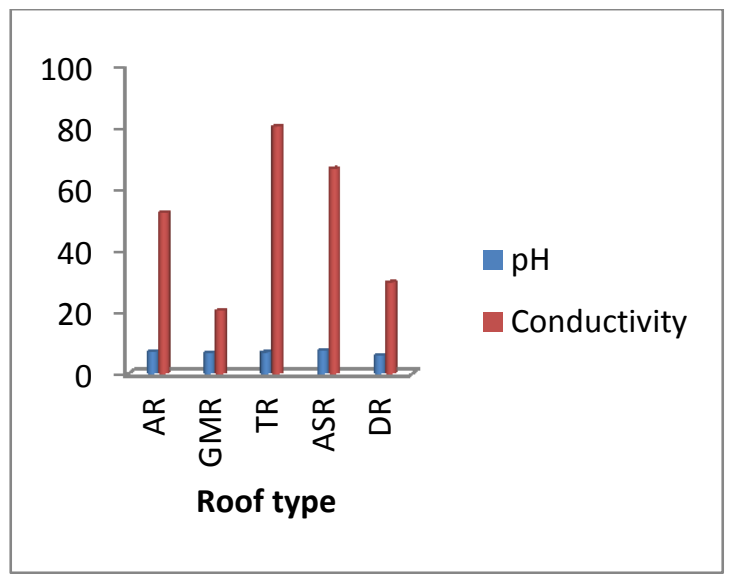

Fig. 2 Variation of mean pH and E.C in runoff samples

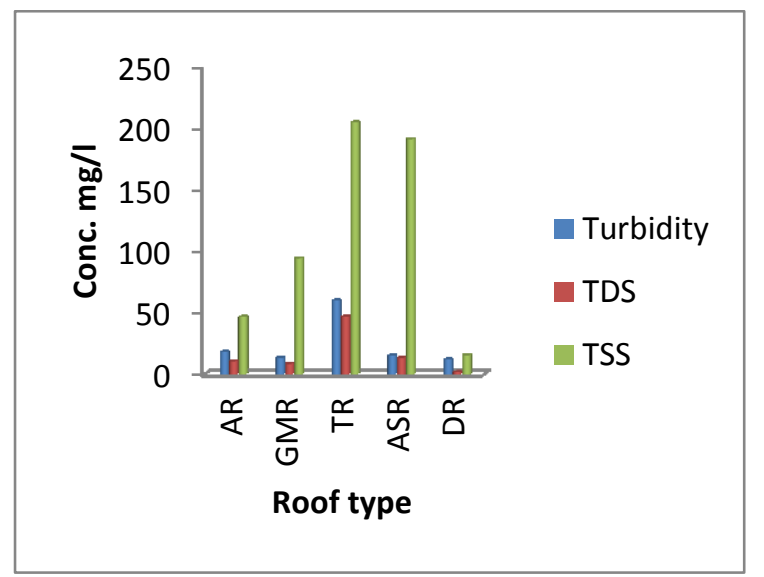

Fig. 3 Mean TDS, TSS and Turbidity level in runoff samples

The concentration of the metal (table land fig.5) detected ranged from $(0.0023 \pm 0.00) \mathrm{mg} / \mathrm{l}$ for Cd in $\mathrm{DR}$ to $(1.1120 \pm 0.07) \mathrm{mg} / \mathrm{l}$ for $\mathrm{Fe}$ in GMR, the heavy metals are in the order $\mathrm{Fe}>\mathrm{Zn}>\mathrm{Cu}>\mathrm{Cd}>\mathrm{Pb}$. The level of $\mathrm{Fe}$ in the roof runoff samples are in the order GMR $>\mathrm{ASR}>\mathrm{AR}>\mathrm{DR}>\mathrm{TR}$. $\mathrm{Cd}, \mathrm{Zn}$ and $\mathrm{Pb}$ were not detected in TR runoff sample. Elevated level of $\mathrm{Cd}, \mathrm{Cu}, \mathrm{Fe}$ and $\mathrm{Pb}$ were observed in ASR roof runoff sample than others, which were above $0.003 \mathrm{mg} / 1$ and $0.01 \mathrm{mg} / 1$ respectively for $\mathrm{Cd}$ and $\mathrm{Pb}$ WHO limit [39]. $\mathrm{Cu}$ and Fe were detected in all the samples and the concentrations are within the WHO limit. Higher values of the metals studied has been reported in a similar study [6,7]. It has been reported that the major source of $\mathrm{Zn}$. $\mathrm{Cu}$ and $\mathrm{Pb}$ in urban runoff water are roof corrosion [17]. Also these metal could

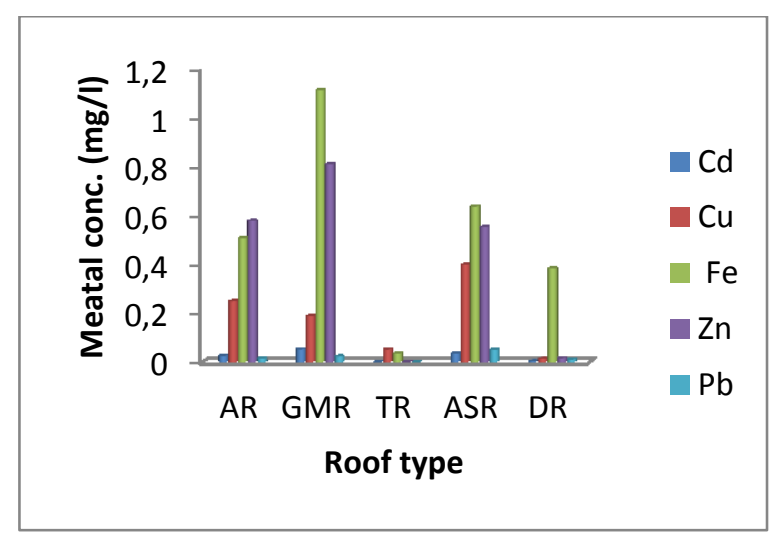

Fig. 4 Mean value of nitrate and phosphate in runoff samples. 


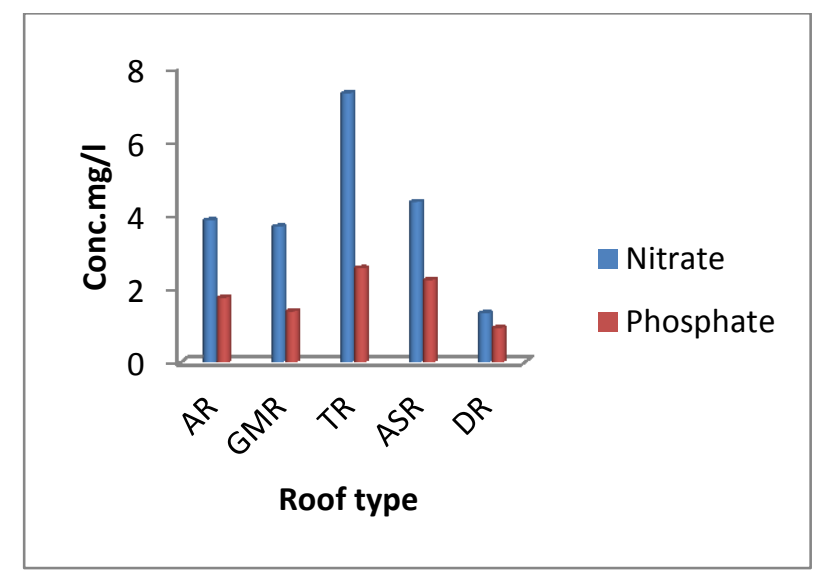

Fig. 5 Mean heavy metal levels in runoff samples.

leached into the environment due to vehicular traffic during tire and brake wearing, gas emissions and corrosion of metallic pieces [16]. Elevated values of $\mathrm{Fe}$ and $\mathrm{Zn}$ in aluminum and galvanized metal roof runoff samples may be due to erosion of zinc roofing material, galvanized gutters and bulk atmospheric deposition [10, 16, 40 41]. Higher value of $\mathrm{Pb}$ and $\mathrm{Cd}$ could be due to tendency of $\mathrm{Pb}$ to strongly adhere to particles [42], $\mathrm{Pb}$ and $\mathrm{Cd}$ are associative [43]. $\mathrm{Cd}, \mathrm{Zn}$ and $\mathrm{Pb}$ which were not detected in TR runoff sample may be due to the tendency of this roof type to retain heavy metals, owing to stabilization of the media through repeated wetting, drying cycles and formation of chelates with organic materials [37,44], since composited biosolids have been found to lower the solubility of $\mathrm{Zn}$ and increases its retention [45].

\section{CONCLUSION}

Though the result of this study showed some variability which is an indication of the type of roofing material; air quality of the environment and industrial activity going on in the area. The study showed that roofs could be a source of pollution since the surfaces are available for deposition of atmospheric particles and the leach-ability of the roof surfaces could have contributed to the level contamination observed in the roof runoff samples. Also it could be deduced from the study that roof runoff may be a non point source of environmental pollution owning to the release of heavy metals and other pollutants into the environment. The increased concentration of some of the pollutants as reported by this study suggests that roof runoff water could impact negatively to the environment and if consumed without being treated may be injurious to human health.

\section{References}

[1] Mendez C. B., Klenzendorf J. B., Afshar B. R., Simmons M. T., M. E. Barrett, Kinney K., Kirisits. M. J. (2011) The effect of roofing material on the quality of harvested Rainwater water $\mathrm{r} e$ s e arch 45, pp 2049 - 2059.

[2] Gregoire B. G., Clausen J. C. (2011) Effect of a modular extensive green roof on stormwater runoff and water quality Ecological Engineering 37, pp 963-9691.

[3] Burton G.A., Jr. I and Pitt, R. (2002) Storm water effects handbook; A tool box for watershed managers, scientists and engineers, CRC, BOCA Raton, Fla.

[4] Clark S.E. Wre P.E.D, Asce M., Steele K.A., Asce A.M., Spicher J. Siu C.Y.S, Lalor M.M., Pitt R. and Kirby J.T. (2008) Roofing materials contribution to storm-water runoff pollution. Journal of Irrigation and drainage Engineering Vol. 134 No. 5. 
[5] Polkowska Z. and Namiesnik J. (2008) Road and roof runoff waters as a source of pollution in a big urban agglomeration (Gidansk, Poland). Ecol. Chem and Eng., 15(3) pp 375-385.

[6] Ayenimo, J.G, Adekunle, A.S, Makinde, W.O. and Ogunlusi, G.O. (2006) Heavy metal fractionation in Roof runoff in Ile-Ife, Nigeria, Internat. J. Environ. Sci. and Tech., 3(3) pp. 221227.

[7] Lamprea K and Ruban V. (2008) Micro pollutants in atmospheric deposition, roof runoff and storm water runoff of a suburban catchment in Nantes, France. $11^{\text {th }}$ International conference on Urban Draiange, Ediburgh, Scotlant, 2008.

[8] Bannerman, R.T., Owens, D.W., Dodds, R.B., Hornewer, N.J., 1993. Sources of pollutants in Wisconsin stormwater. Water Sci. Technol. 28, 241-259.

[9] Egodawatta, P., Thomas, E., Goonetilleke, A., 2009. Understanding the physical Processes of pollutant build-up and wash-off on roof surfaces. Sci. Total Environ. 407, 1834-1841.

[10] Förster, J., 1996. Patterns in roof runoff contamination and their implications on practice and regulation of treatment and local infiltration. Water Sci. Technol.33, 39-48.

[11] Van Metre P.C. and Mahler B.J. (2003) The contribution of particles washed from rooftops to contaminate loading to urban streams, chemosphere 52(10) pp. 1727-1741.

[12] Boulanger, B., Nikolaidis, N.P., 2003. Mobility and aquatic toxicity of copper in an urban watershed. J. Am.Water Resour. Assoc. 39, 325-326.

[13] Njoku P.C. and Ibe F.C. (2009) Heavy metal accumulation in electronic technician in Owerri JCSN, Vol. 34 91) Pp. 1-4.

[14] Tobiszewski M., Polkowska Z., Konieczka P. and Manuenik J. (2010) Roofing materials as pollution eemitters concentration changes during runoff polish J. of Environ. Stud. Vol. 19 No. 5 pp. 1019-1028.

[15] Forster J. (1999) variability of roof runoff quality. Wat Sci Tech. 35 (5) Pp. 137-144.

[16] Chang M., McBroom M.W and Beasley R.S (2004) Roofing as a source of non point water pollution, J. Environ. Man. 73 (4) Pp. 307-315.

[17] Gromaire -Mertz M.C., Garnaud S., Saad M. and Chebbo G. (2001) Contribution of different sources to the pollution of wet weather flow in combined sewers. Wat. Res., 35(2) Pp 521-533.

[18] Van Metre P.C. and Mahler B.J. (2003) The contribution of particles washed from Roof tops to contaminate loading to urban streams, chemosphere, 52(10) pp1727-1741.

[19] Nichelson N., Clark S.K., Long B.V Spicher J. and Steele K.A. (2009) Rain water harvesting for non-potable use in gardens: a comparism of runoff water quality from green vs traditional roofs in proceedings of world Environmental and water resources congress 2009. Great River Kansas city, Missouri. 
[20] Mendez B.C., Afshar B.R., Kinney K., Barrett M.E and Kirisits M.J. (2010) Effect of roof material on water quality for rainwater harvesting stems. Texas water Development board Report, Capital station, Austin, Texas 78711-3231, January 2010 report, the University of Texas at Auston.

[21] Olaoye R.A and Olaniyan, O.S (2012) Quality of rainwater from different roof material. internet. J .of Eng. And Tech Vol. 2 (8) Pp. 1413-1421.

[22] Despin C., Farahbakhsh, K. and Leidl C. (2009) Assessment of rainwater quality from rainwater harvesting systems in Ontario, Canada, Journal of water supply: Research and Technology-Aqua 58 (2) Pp. 117-134.

[23] Efe S.I. (2006). Quality of rainwater harvesting for rural communities of Delta State Nigeria. The Environment 26(3): Pp. 175-181.

[24] Egereonu U.U (2005) A study of the ground water pollution by nitrate in the environment, Aba, Nigeria, JCSN 30 (2), Pp. 211-218.

[25] Akintola O.A, Sangodoyin AY and Agumbiade F.O. (2013) Evaluation of environmental pollution effects on domestic roof-harvested rainwater in southern part of Nigeria using impact indices. Water practice and Technology 8(2) Pp 245-255.

[26] Allen S.E, Grimshaw H.M, Parkinson J.A and Quamby C. (1974) Chemical analysis of ecological materials, Blackwell scientific publications, Oxford, London, pp 103, 104.

[27] Egereonu U.U.and Ozuzu C.I.U. Physiochemical analysis of the River Niger at Onitsha Bank, Nigeria (2005) J.Chem. Soc. Nigeria 30 (2) pp 197 - 203.

[28] Ibe F.C., Chinedu N. B. and Ikpa C.B.C (2014) Physiochemical analysis of some surface and ground water sources in Etim Ekpo, LGA, Akwa Ibom State, Nigeria. Journal of Applied Sciences AS 17(2) pp $11250-11260$.

[29] Njoku V.O., Obi C. and Obodo G.A (2007) Heavy metals concentrations in some surface and ground waters in Imo State, Int. J. of Natural and Applied Sci. 3(2), pp 157-159.

[30] Zhang W., Li S., and Tang F., (2013) Characterization of Urban Runoff Pollution between Dissolved and Particulate Phases. The Scientific World Journal. Volume 2013, Article ID 964737, 6 pages. 2013. Available at: http://dx.doi.org/10.1155/2013/964737(Accessed on July 12 2013).

[31] Simmons G., Hope V., Lewis G., Whitmore J., and Wanzhen G., (2001) Contamination of potable roof-collected rainwater in Auckland, New Zealand. Water Res. 35, 2001, pp 1518-1524.

[32] Adedeji O.H. and Olayinka O.O (2014) Micro-pollutants in urban residential roof runoff. Environmental and health implication 10SR-JESTFT 8(2) version (III) Pp. 55-63.

[33] Lee J.Y., Yang J.S., Han M., Choi J., (2010) Comparison of the microbiological and chemical characterization of harvested rainwater and reservoir water as alternative water resources. Science of the Total Environment 408 (4), pp 896 - 905.

[34] Yaziz, M.I., Gunting, H., Sapari, N., Ghazali, A.W., 1989. Variations in rainwater quality from roof catchments. Water Research 23(6), pp 761-765. 
[35] Lee J.Y., Bak G., Han M. (2012) Quality of roof-harvested rainwater-comparison of different roofing materials. Environ. Pollut. 162, 422-429.

[36] Singh, T., Kalra, Y.P., (1975). Specific conductance method for in situ estimation of total dissolved solids. Journal of American Water Works Association 67 (2), pp 99 -100.

[37] Quek U. and Forster J. (1993) Trace metals in roof runoff. Water, Air and Soil pollution 68, 373-389.

[38] Berndtsson J.C, Bengtson L. and Jinno K (2009) Runoff water quality from intensive and extensive vegetated roofs. Ecol. Eng., 35, Pp 369-380.

[39] WHO (2003) WHO Guildelines for drinking water quality, Geneva. http://www. who. int/water_health/dwq/guideline/en/(accessed 5, May 2014).

[40] Gromaire-Mertz M.C., Garnauds, Gionzalez A. and Chebbo G. (1999). Characterization of Urban runoff pollution in Paris. Wat. Sci.Tech., 39(2) Pp.1-8.

[41] Uzoma V.C Alsangodoyin A.Y. (2000) Rainwater chemistry as Influenced by atmospheric deposition of pollutants in southern Nigeria. Environ. Manage Health, 11 (2), 149-156.

[42] Dannecker W., AUM and Stedimann, H (1990) Substances load in rainwater runoff from different streets in Hamburg. Sci. Tet. Environ, 93, Pp. 385-392.

[43] Alloway B.J. and Ayres D.C. (1997) Chemical Principles of Environmental Pollution, $2^{\text {nd }}$ Ed., Blackie Academic and Professional. Pp. 196.

[44] Han F.X., Banin A., Triplett G.B., (2001) Redistribution of heavy metals in arid-Ozone soil under a wetting-drying cycle soil moisture regime. Soil Sci. 166, pp 18-28.

[45] Madrid F and Florido M.C. (2010) Effects of the presence of composted biosolids on the metal immobilizing action in an urban soil. J. Hazard, Mater. 176, Pp. 792-798. 